\title{
Isolation, characterization and nucleotide sequences of the aro $C$ genes encoding chorismate synthase from Salmonella typhi and Escherichia coli
}

\author{
Ian G. Charles, ${ }^{1}$ Heather K. Lamb, ${ }^{2}$ Derek PiCkard, ${ }^{1}$ Gordon Dougan ${ }^{1}$ and \\ Alastair R. HaWkins ${ }^{2 *}$ \\ ${ }^{1}$ Department of Molecular Biology, Wellcome Research Laboratories, Langley Park, South Eden Park Road, \\ Beckenham, Kent BR3'3BS, UK \\ ${ }^{2}$ Department of Biochemistry and Genetics, University of Newcastle upon Tyne, Framlington Place, \\ Newcastle upon Tyne NE2 4HH, UK
}

(Received 3 August 1989; revised 20 October 1989; accepted 3 November 1989)

\begin{abstract}
The aroC genes from Salmonella typhi and Escherichia coli, encoding 5-enolpyruvylshikimate-3-phosphate phospholyase (chorismate synthase) were cloned in $E$. coli and their DNA sequences were determined. The aroC gene from $S$. typhi was isolated from a cosmid gene bank by complementation of an $E$. coli aroC mutant. The corresponding $E$. coli gene was isolated from a pBR322 gene bank by colony hybridization using DNA encoding the aro $C$ gene from $S$. typhi as a hybridization probe. Analysis of the nucleotide sequence revealed that both genes have an open reading frame capable of encoding proteins comprising 361 amino acids. The calculated molecular mass of the protein from $S$. typhi is $39108 \mathrm{Da}$ while that of the protein from $E$. coli is $39138 \mathrm{Da}$. Homology is particularly strong between the coding regions of the genes: $95 \%$ when protein sequences are compared, and $83 \%$ when DNA sequences are examined. Use of a deletion variant of the $E$. coli aro $C$ gene demonstrates that the $C$-terminal 36 amino acids are not essential for the correct folding or functional activity of the chorismate synthase enzyme.
\end{abstract}

\section{Introduction}

The biosynthesis of aromatic compounds including the aromatic amino acids $p$-aminobenzoic acid and 2,3dihydroxybenzoate is of great importance for the growth and survival of bacterial cells. The only biosynthetic route for aromatic compounds possessed by microorganisms is the shikimate pathway which leads to the synthesis of chorismic acid, a central precursor for other aromatic compounds (Giles, 1978; Pittard, 1987). The shikimate pathway is present in bacteria, yeasts and in plant cells, but is absent from mammalian cells. As a consequence, enzymes in the shikimate pathway have been identified as potential targets for chemotherapeutic agents (Kishore \& Shah, 1988). Because of the importance of the shikimate pathway, attention has turned to the individual enzymes responsible for aromatic compound biosynthesis. At least seven enzymes are

Abbreviation: EPSP, 5-enolpyruvylshikimate 3-phosphate.

The nucleotide sequence data for E. coli and S. typhi reported in this paper have been submitted to GenBank and have been assigned the accession numbers M27714 and M27715, respectively. required for the synthesis of chorismic acid from nonaromatic precursors. Chorismate synthase (5-enolpyruvylshikimate-3-phosphate phospholyase; EC 4.6.1.4) is the final enzyme in the pathway and catalyses the conversion of 5-enolpyruvylshikimate 3-phosphate (EPSP) to chorismic acid. The enzyme chorismate synthase has been purified and characterized from a variety of micro-organisms (White et al., 1988) and plant sources (Mousdale \& Coggins, 1986).

Pathogenic bacteria carrying mutations in genes encoding enzymes in the shikimate pathway (Bacon $e t$ al., 1951) such as aro $A$ (Dougan et al., 1987; O'Callaghan et al., 1988) grow poorly in vivo and are of potential use as live vaccines. A long-term objective of this research is to use the deduced primary amino acid sequences of the chorismate synthase enzymes in a pharmacological study of the interaction of potential inhibitors with the protein. Significantly, the five monofunctional aro enzymes producing EPSP in $E$. coli have previously been shown to have conserved regions when compared with the equivalent pentafunctional $A R O M$ (Giles, 1978) locus of the eukaryote Aspergillus nidulans (Hawkins, 1987). To obtain some measure of the conservation of the protein sequences of the chorismate synthase enzymes we 
describe the cloning and sequencing of the aroC genes of $S$. typhi and E. coli. In addition, we present initial data on the size of functional domains within the chorismate synthase enzyme using deletion variants of the $E$. coli aroC gene.

\section{Methods}

Strains, bacteriophage and plasmids. E. coli TG1 [K $12 \Delta$ (lac-pro) supE thi hsdD5/ $\mathrm{F}^{\prime}$ traD36 pro $A^{+} B^{+}$lac $I^{\mathrm{q}}$ lacZ $\Delta \mathrm{M} 15$ (Carter et al., 1985)] and $\lambda$ b221 cI857 Oam29 Pam80 rex::Tn5 (de Bruijn \& Lupski, 1984) were the kind gifts of Dr T. Gibson, Laboratory of Molecular Biology, Cambridge, UK, and Dr T. Foster, Trinity College Dublin, Ireland, respectively. E. coli GLW40 (aroC thi recA13) was the kind gift of DrI. Hunter, Institute of Genetics, Glasgow University, UK. E. coli HB101 and $S$. typhi Ty2 aroA :: $\mathrm{Tn} 10$ (Dougan et al., 1987) were as previously described. BRD049 is an $E$. coli $\mathrm{K} 12$ strain harbouring a stable mutation in aroC (White et al., 1988). Cosmid pHC79 (Hohn \& Collins, 1980) was from Amersham; plasmid pBR322 was as described previously (Bolivar et al., 1977) and M13mp18 and M13mp19 (Messing $\&$ Vieira, 1982) were supplied by Pharmacia. Minicells were prepared using E. coli strain DS410 (Dougan \& Sherratt, 1977). E. coli strain C600 was as previously described (Appleyard, 1954).

$M e d i a$ and reagents. S. typhi and $E$. coli strains were grown in Luria broth (LB) or on LB solidified with $1.6 \%$ (w/v) agar (Miller, 1972) (Difco). Minimal medium (MM) was made as described by Miller (1972) and was solidified with $2 \%$ (w/v) Noble Agar (Difco). Deoxyand dideoxynucleotides, ampicillin, tetracycline, dithiothreitol and aromatic amino acids were from Sigma. Restriction endonucleases were from BRL Gibco and Pharmacia. T4 DNA ligase was from Boehringer and Klenow fragment of DNA polymerase I was from Pharmacia.

DNA isolation, Tn5 mutagenesis and minicells. Chromosomal DNA was isolated using the method of Hull et al. (1981) as outlined by Maskell et al. (1988). Tn 5 mutagenesis and mapping was done with $\lambda:: \operatorname{Tn} 5$ using the method described previously by de Bruijn $\&$ Lupski (1984). Minicells and SDS-PAGE were as described previously (Dougan \& Sherratt, 1977).

Cloning of S. typhi chromosomal DNA in cosmid pHC79. Cosmid vector pHC79 (Hohn \& Collins, 1980) was digested with BamHI and ligated with Sau3A-digested S. typhi DNA in the 40-50 kb size-range, as outlined previously (Maniatis et al., 1982; Morrissey \& Dougan, 1986). In vitro packaging of ligated molecules was done with a Gigapack kit (Strategene; Northumbria Biologicals) using the manufacturer's recommended conditions. E. coli HB101 recipient cells were infected with recombinant phage and plated on LB-ampicillin $\left(50 \mu \mathrm{g} \mathrm{ml}^{-1}\right)$. Putative recombinants, identified by their Ampr $\mathrm{Tet}^{\mathrm{s}}$ phenotype, were picked into microtitre plates containing, in each well, LB $+50 \%(\mathrm{v} / \mathrm{v})$ glycerol $+50 \mu \mathrm{g}$ ampicillin $\mathrm{ml}^{-1}$. Plates were incubated at $37^{\circ} \mathrm{C}$, then stored frozen at $-70^{\circ} \mathrm{C}$.

DNA sequencing. DNA sequencing of the aroC genes from $S$. typhi and $E$. coli was done using universal primer, $\left[\alpha^{-35}\right.$ S $]$ dATP (deoxyadenosine $5^{\prime}-\left[\alpha^{-35} S\right]$ thiotriphosphate) dideoxynucleotide triphosphates, and both gradient and wedge gels (Biggin et al., 1983; Sanger et al., 1977).
Some clones were sequenced with modified T7 DNA polymerase (Tabor \& Richardson, 1987) using the Sequenase kit (United States Biochemical Corporation; marketed by Cambridge BioScience). Gaps in the sequences were filled by using synthetic oligonucleotides as specific primers (Charles et al., 1985, 1986). Some master templates for use with specific oligonucleotide primers were prepared from $100 \mathrm{ml}$ cultures, the phage DNA being purified further by a $\mathrm{CsCl}$ gradient step (Strauss et al., 1986).

Oligonucleotides. Oligonucleotides, for use as specific sequence primers, were made on a SAM I oligonucleotide synthesizer (Biolabs), or manually by the paper-disc method (Matthes et al., 1984) with modifications to the wash-cycle as described by Sproat \& Gait (1985).

\section{Results and Discussion}

Cloning and mapping of the S. typhi gene for aroC in E. coli

Cosmid recombinants containing $S$. typhi inserts were packaged in vitro and used to infect $E$. coli HB101. A master gene bank of 600 individual recombinants was picked into microtitre plates and frozen at $-70{ }^{\circ} \mathrm{C}$. In addition, approximately 600 individual colonies were harvested from a plate and used to prepare plasmid DNA. The resulting DNA was used to transform an $E$. coli aroC host (BRD049) and transformants were selected on $\mathrm{MM}$ containing ampicillin but lacking aromatic compounds. A recombinant that grew well was selected for further analysis. After demonstrating retransformation and complementation of the aroC lesion of BRD049, plasmid DNA was prepared and designated pWAC6. pWAC6 was subjected to restriction-enzyme mapping, transposon mutagenesis and DNA-sequence analysis.

The recombinant pWAC6 was only $11.0 \mathrm{~kb}$ in size, with an insert of $4.5 \mathrm{~kb}$ of $S$. typhi-derived DNA, suggesting that $\mathrm{pWAC} 6 \mathrm{had}$ arisen by deletion of a larger cosmid. Transposon mutagenesis identified a $3.8 \mathrm{~kb}$ SphI-EcoRI fragment, which was subcloned from pWAC6 into pUC8 to form the recombinant plasmid pSE7; it was also able to complement the aroC lesion in BRD049.

\section{Cloning of the E. coli C600 aroC gene}

Samples of chromosomal DNA from E. coli C600 were digested separately with the restriction endonucleases $C l a \mathrm{I}$ and $S a I I$, separated on a $0.7 \%(\mathrm{w} / \mathrm{v})$ agarose gel and transferred to nitrocellulose by the method of Southern (1975). The resulting filter was probed with a PstI-NruI fragment from the $S$. typhi aroC gene that had been labelled with $\left[\alpha^{-32} \mathrm{P}\right] \mathrm{dCTP}$ (Maniatis et al., 1982).

Fig. 1 ( facing page). Nucleotide and deduced amino acid sequences of the aroC gene from $S$. typhi (upper case) and E. coli (lower case). The horizontal arrows indicate regions of imperfect inverted repeat; the overlined sequences at positions 292-295 and 446-451 in $S$. typhi and E. coli, respectively, indicate putative ribosome-binding sites. The protein sequences are shown in the single-letter code. Unique $E$. coli DNA sequence is shown in full, but where it overlaps with $S$. typhi sequence, only the nucleotide and amino acid differences are indicated. 
getgaacagaacatcgaagaacacggtctgatccacạacgtcattecgattcgttccgatctgttecgcg̣acttgecgaaggtgcagtacģacctgattgtcaetaaccegcegtatgtc 120

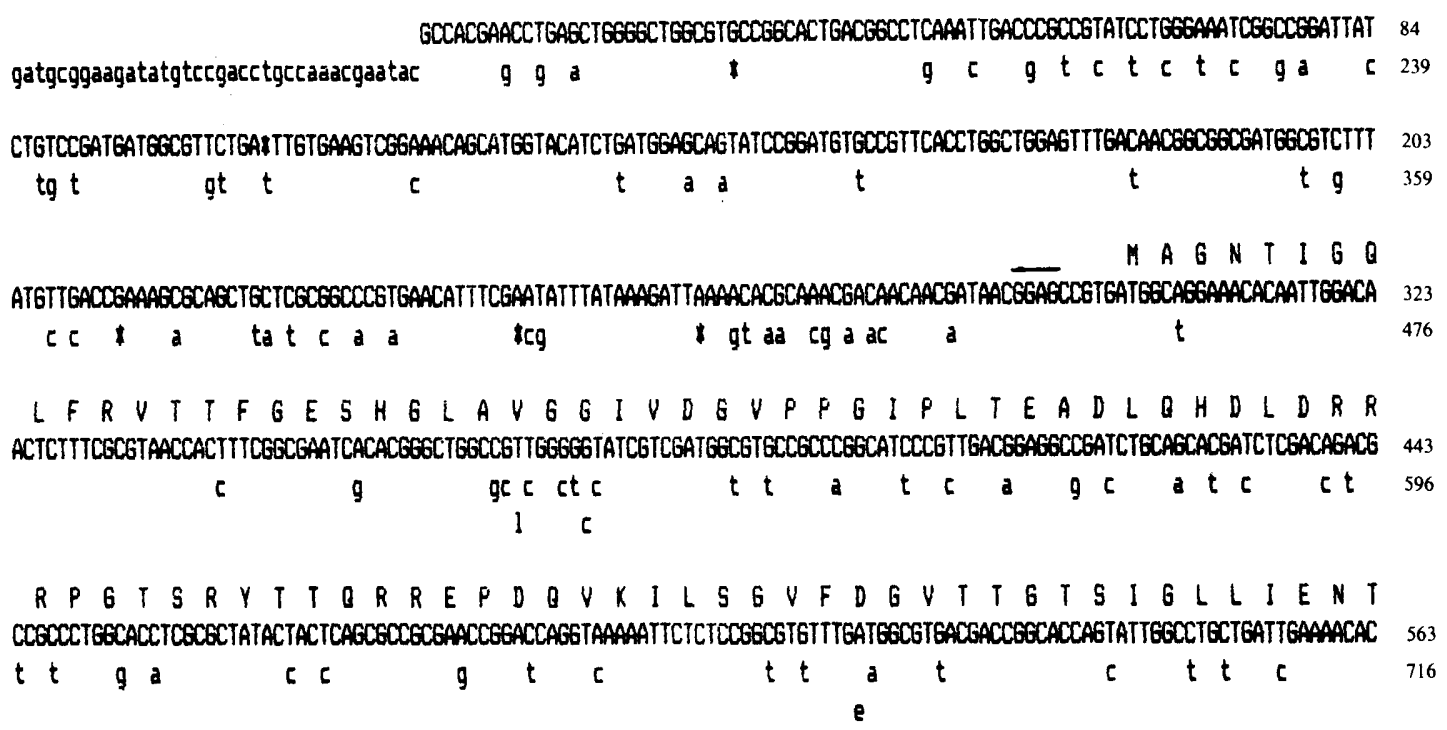

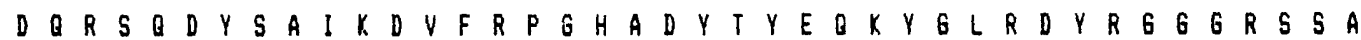

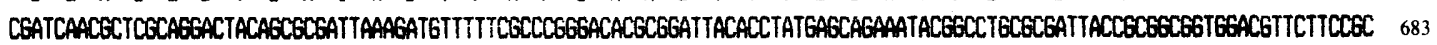

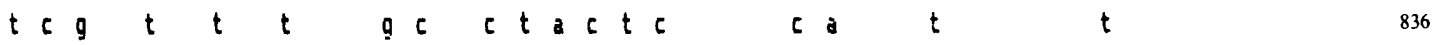
RE T A I V V A A G A I A KKY Y A E K F G I E I R G C L T O A G D I P L E I K

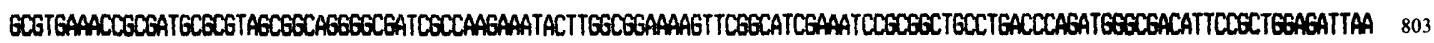

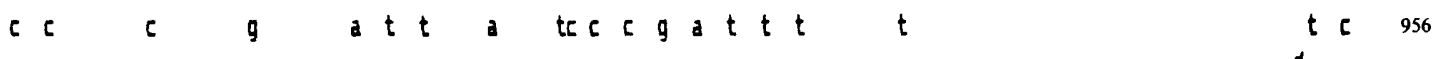

DWR QVELN P F F C D D DKLDALDELMRALKKE

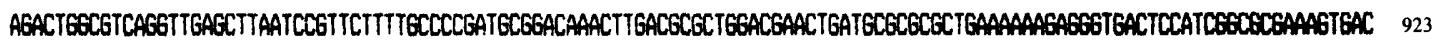

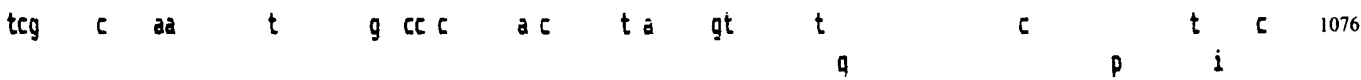

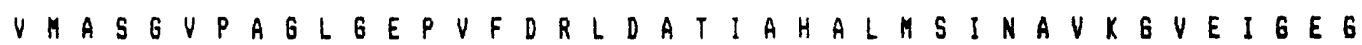

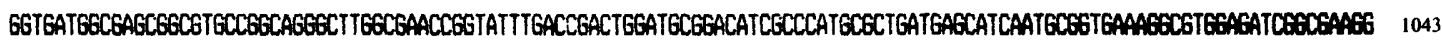

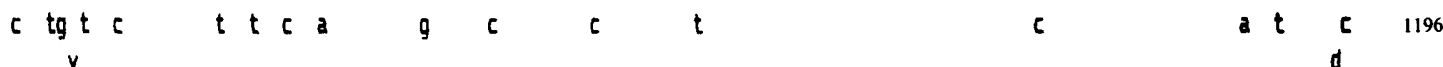

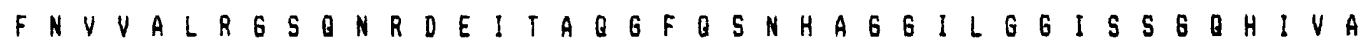

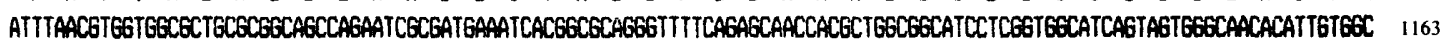

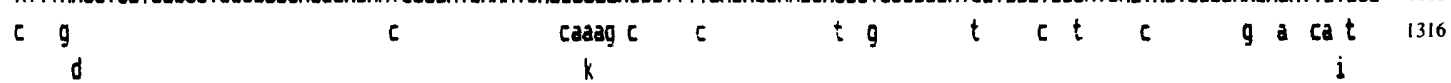
H M A L K P T S S I T V P GR TINR M GE EVEMITKGR H D P C V G IRA

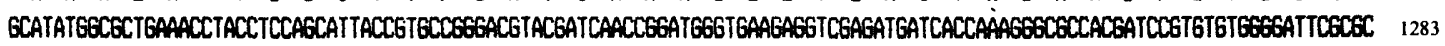

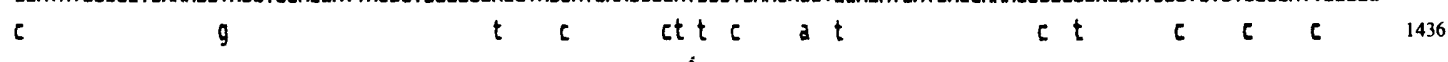
V P I A E A HLA I VTM DHLLR HR A Q NA D V K T E I PR U U

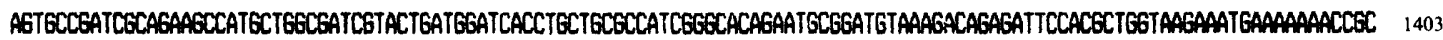

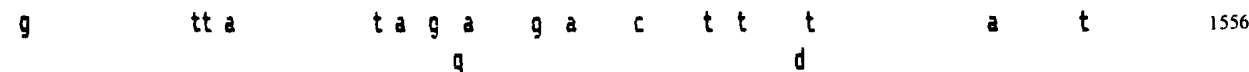

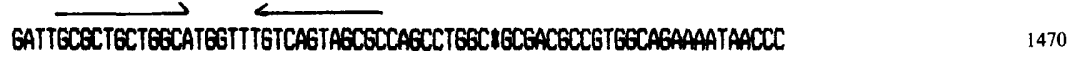
tet $C$ C a $\quad$ a a acctgtgecgggtagege 1644 
Analysis of the Southern blot (data not shown) demonstrated hybridization to a $3.0 \mathrm{~kb} C l a I$ fragment, and a $4.7 \mathrm{~kb} S a l \mathrm{I}$ fragment. Size-selected $S a I I$ restriction fragments of $E$. coli C600 DNA in the range of 4-5 kb were purified from a gel by the freeze-squeeze method (Tautz \& Renz, 1983) and ligated into pBR322 digested with SalI.

After transformation of $E$. coli $\mathrm{C} 600$ approximately $2000 \mathrm{Amp}^{\mathrm{r}}$ colonies were recovered, lysed in situ on nitrocellulose, and probed with the $\alpha^{-32}$ P-labelled PstI$\mathrm{NruI}$ fragment from the $S$. typhi aroC gene. A single colony showing hybridization to the probe contained a plasmid designated pAN10. This plasmid contained a $4.7 \mathrm{~kb}$ Sall fragment, and was capable of complementing the $E$. coli aro $C$ mutation following re-transformation.

\section{DNA sequencing of the $S$. typhi and $E$. coli aroC genes}

The DNA sequences of the two aroC genes were determined using universal primer, and specific oligonucleotides to extend and overlap the sequences on both strands. Analysis of the DNA sequences revealed open reading frames encoding proteins of 361 amino acids of molecular mass $39108 \mathrm{Da}$ and $39138 \mathrm{Da}$ for the $S$. typhi and $E$. coli genes, respectively. Fig. 1 compares the $S$. typhi and $E$. coli DNA sequences, and the two deduced protein sequences.

\section{Polypeptide expression from aroC recombinants in minicells}

Plasmid pWAC6 encoding the $S$. typhi aroC gene was transferred into the minicell-producing strain DS410. Plasmid-harbouring minicells were purified, labelled with $\left[{ }^{35}\right.$ S $]$ methionine and analysed using SDS-PAGE and autoradiography, following immunoprecipitation with antibody raised against $E$. coli chorismate synthase (kindly supplied by J. Coggins, University of Glasgow, UK). The results are shown in Fig. 2. The aroCcomplementing plasmid pWAC6 produced a $40 \mathrm{kDa}$ polypeptide (in addition to some other non-specific proteins that were also immunoprecipitated). This polypeptide is absent from the control minicell preparation containing pHC79 vector alone (track 2) and is in good agreement with the value of $39.1 \mathrm{kDa}$ for the deduced protein encoded by the $S$. typhi aroC gene, suggesting strongly that this polypeptide is the $S$. typhi chorismate synthase enzyme. The $40 \mathrm{kDa}$ polypeptide could not be distinguished when whole-cell preparations of BRD049 harbouring aroC-positive recombinant plasmids were analysed using SDS-polyacrylamide gels stained with Coomassie blue (data not shown). Thus the

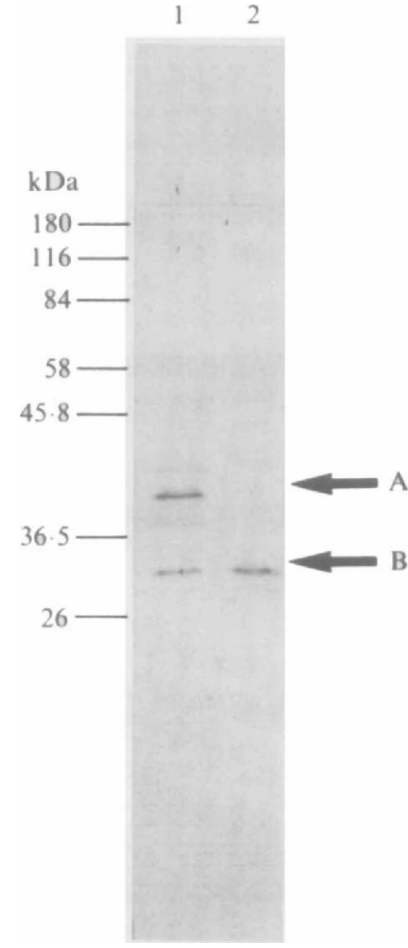

Fig. 2. Autoradiogram showing $\left[{ }^{35} S\right]$ methionine-labelled minicell preparations following immunoprecipitation with antibody raised against $E$. coli chorismate synthase. Track 1, pWAC6; track 2, pHC79. Arrow A indicates the position of a $40 \mathrm{kDa}$ band in track 1 corresponding to chorismate synthase. Arrow B indicates the position of $30 \mathrm{kDa}$ bands present in the negative control (track 2), as well as in track 1 , that are incidental to chorismate synthase.

chorismate synthase of $S$. typhi was expressed at a relatively low level in $E$. coli.

\section{Putative regulatory elements for the aroC genes}

Neither gene has exact matches with the consensus -10 and -35 promoter elements (Rosenberg \& Court, 1979). However, putative -10 elements from positions 201205 (S. typhi) and 406-411 (E. coli), and -35 elements from positions 178-183 (S. typhi) and 383-388 (E. coli) were identified by eye. The sequence GGAG is found at positions 292-295 (S. typhi) and 446-449 (E. coli) and shows good agreement with the consensus $E$. coli ribosome-binding site (Shine \& Dalgarno, 1974). Imperfect inverted repeats are found at 3'-positions 1408-1436 (S. typhi) and 1562-1590 (E. coli), which have calculated $\Delta G^{0}$ values (Tinoco et al., 1973) of $-47.7 \mathrm{~kJ} \mathrm{~mol}^{-1}(S$. typhi), and $-85.4 \mathrm{~kJ} \mathrm{~mol}^{-1}$ (E. coli), but differ from typical $E$. coli rho-independent terminators in that they are not followed by a run of uridine residues. 


\section{Comparison of the $S$. typhi and $E$. coli aroC sequences}

Alignment of the two sequences demonstrates very strong homology between the two coding regions of the genes, $95 \%$ at the protein level and $84 \%$ at the DNA level (Fig. 1). Many of the observed protein changes are conservative substitutions, both genes comprising 361 codons and using TAA as the termination codon.

Examination of the codon-usage table (data not shown) for the two genes shows a high degree of similarity, and is consistent with those $E$. coli genes that are weakly expressed (Grantham et al., 1981). There are some differences in codon preference, however; the codon for valine most often used in the $E$. coli aroC is GTT, while this is infrequently used in $S$. typhi. The $\mathrm{G}+\mathrm{C}$ ratio for the $S$. typhi aroC gene is $59 \mathrm{~mol} \%$ while for the $E$. coli aroC gene the $\mathrm{G}+\mathrm{C}$ ratio is $57 \mathrm{~mol} \%$. There is less apparent homology when the $5^{\prime}$ and $3^{\prime}$ noncoding regions of the two sequences are compared. Both genes exhibit a region of imperfect inverted repeat sequence $22 \mathrm{bp}$ after the TAA stop codon, although there are base variations in this $22 \mathrm{bp}$ region, and in the inverted repeat itself. When the $5^{\prime}$ non-coding regions of the two genes are compared, the direct base-for-base homology observed in the coding region disappears, although both sequences have a candidate ribosomebinding site with the sequence $5^{\prime}-\mathrm{GGAG}-3^{\prime}$.

There is considerable divergence between the deduced C-terminal sequences of the aroC-encoded proteins reported here and a recently reported $E$. coli aro $C$ sequence (White et al., 1988). The differences arise from the fact that there is an additional A-base (at position 1457 in Fig. 1) in the sequence of White et al. (1988). This additional base leads to a change in the reading frame, producing a difference in the sequence of the $27 \mathrm{C}$ terminal amino acids. There are two other DNA sequence differences; at positions 126 and 151 an extra G-base is present in the sequence presented here. These differences potentially identify a polymorphism between the strain used by White et al. (1988) and the C600 isolate used in this study. To test whether the C-terminal amino acids are functionally critical for the correct folding and functioning of chorismate synthase, a deletion mutant was constructed. A SalI-BamHI fragment of the E. coli aro $C$ gene, lacking the $C$-terminal 36 amino acid residues, was inserted into suitably digested pBR322 to produce plasmid pAN11. An $E$. coli recA aroC strain (GLW40) transformed with this plasmid was capable of growth on minimal medium lacking aromatic amino acid supplements. This demonstrated that the SaII-BamHI fragment can be translated to form a truncated protein that is capable of folding to give functional chorismate synthase activity. It is possible, then, that both published sequences can occur in nature and that the C-terminal 36 amino acids are not absolutely critical for the correct folding and expression of chorismate synthase.

By replacing the natural $a r o C$ promoter of $S$. typhi with a more powerful promoter it should be possible to construct an $E$. coli strain expressing high levels of chorismate synthase which would facilitate purification of the enzyme. The purified enzyme will be useful for screening in vitro for chemical inhibitors of enzyme activity. Eventually, we intend to use information from the DNA sequence to construct specific mutants of the chorismate synthase enzyme which will be useful for studying the interaction of potential inhibitors with the protein.

This research was supported in part by grant GR/D/74697 from the SERC 'Antibiotics and Recombinant DNA Initiative', and a Wellcome Trust grant funding manual oligonucleotide synthesis in Newcastle, both awarded to A.R.H.

We thank Professor J. Coggins for supplying antibody to E. coli chorismate synthase, Hugh Spence and Pauline Heslop for making oligonucleotides, Steve Nicholls for advice on computing and Irene Stobbs for typing the manuscript.

\section{References}

APPLEYARD, R. K. (1954). Segregation of new lysogenic types during growth of a doubly lysogenic strain derived from Escherichia coli K12. Genetics 39, 440-452.

Bacon, G. A., Burrows, T. W. \& Yates, M. (1951). The effects of biochemical mutation on the virulence of Bacterium typhosum: the loss of virulence of certain mutants. British Journal of Experimental Pathology 32, 85-96.

Biggin, M. D., Gibson, T. J. \& Hong, G. F. (1983). Buffer gradient gels and ${ }^{35} \mathrm{~S}$ label as an aid to rapid DNA sequence determination. Proceedings of the National Academy of Sciences of the United States of America 80, 3963-3965.

Bolivar, R., Rodriguez, R. L., Green, P. J., Betlach, M. C., HeYNeCKer, H. L., Boyer, H. W., Crosa, J. H. \& Falkow, S. (1977). Construction and characterisation of new cloning vehicles. II. A multipurpose cloning system. Gene 2, 95-101.

DE BRUIJN, F. J. \& LUPSKI, J. R. (1984). The use of transposon Tn5 mutagenesis in the rapid generation of correlated physical and genetic maps of DNA segments cloned into multicopy plasmids - a review. Gene 27, 131-149.

Carter, P., Bedouelle, H. \& Winter, G. (1985). Improved oligonucleotide site directed mutagenesis using M13 vectors. Nucleic Acids Research 13, 4431-4443.

Charles, I. G., Keyte, J. W., Brammar, W. J. \& Hawkins, A. R. (1985). Nucleotide sequence encoding the biosynthetic dehydroquinase function of the penta-functional $A R O M$ locus of Aspergillus nidulans. Nucleic Acids Research 13, 8119-8128.

Charles, I. G., Keyte, J. W., Brammar, W. J., Smith, M. \& Hawkins, A. R. (1986). The isolation and nucleotide sequence of the complex AROM locus of Aspergillus nidulans. Nucleic Acids Research 14, 22012213.

Dougan, G. \& SherRatT, D. J. (1977). Tn $a$ as a probe for the structure and function of ColE1. Molecular and General Genetics 151, 151-160.

Dougan, G., Maskell, D., Pickard, D. \& Hormaeche, C. (1987) Isolation of stable aroA mutants of Salmonella typhi Ty2: properties and preliminary characterisation in mice. Molecular and General Genetics 207, 402-405.

GiLES, N. H. (1978). The organisation, function and evolution of gene clusters in eukaryotes. American Naturalist 112, 641-657.

Grantham, R., Gautier, C., Gouy, M., Jacobzone, M. \& Mercier, R. (1981). Codon catalogue usage is a genome strategy modulated for gene expressivity. Nucleic Acids Research 9, 43-47. 
Hawkins, A. R. (1987). The complex AROM locus of Aspergillus nidulans: evidence for multigene fusions and convergent evolution. Current Genetics 11, 491-498.

HoHN, B. \& Collins, J. (1980). A small cosmid for efficient cloning of large DNA fragments. Gene 11, 291-298.

Hull, R. A., Gill, R. E., Hsu, P., Minshew, B. H. \& Falkow, S. (1981). Construction and expression of recombinant plasmids encoding type 1 of D-mannose-resistant pili from a urinary tract infection Escherichia coli isolate. Infection and Immunity 33, 933-938.

Kishore, G. M. \& ShaH, D. M. (1988). Amino acid biosynthesis inhibitors as herbicides. Annual Review of Biochemistry 57, 627-663.

Maniatis, R., Fritsch, E. F. \& SAmbrook, J. (1982). Molecular Cloning: a Laboratory Manual. Cold Spring Harbor, NY: Cold Spring Harbor Laboratory.

Maskell, D. J., MoRrissey, P. \& Dougan, G. (1988). The cloning and nucleotide sequence of the aroA gene of Bordetella pertussis. Journal of Bacteriology 170, 2467-2471.

Matthes, H. W. D., Zenke, W. M., Grundstrom, T., Staub, A., WinTzerith, M. \& Chambon, P. (1984). Simultaneous rapid chemical synthesis of over one hundred oligonucleotides on a microscale. EMBO Journal 3, 801-805.

Messing, J. \& VieIRA, J. (1982). A new pair of M13 vectors for selecting either DNA strand of double digested restriction fragments. Gene 19, 269-276.

Miller, J. M. (1972). Experiments in Molecular Genetics. Cold Spring Harbor, NY: Cold Spring Harbor Laboratory.

MoRrissey, P. \& Dougan, G. (1986). Cloning and characterisation of the Escherichia coli $987 \mathrm{P}$ adhesion fimbriae determinant. Gene 43, 79-84.

Mousdale, D. M. \& CogGins, J. R. (1986). Detection and subcellular localization of a higher plant chorismate synthase. FEBS Letters 205, 328-332.

O'Callaghan, D., Maskwell, D., Liew, F. Y., Easmon, C. S. \& DougaN, G. (1988). Characterization of aromatic and purine dependent Salmonella typhimurium: attenuation, persistence and ability to induce protective immunity in BALB/c mice. Journal of Bacteriology 56, 419-423.
Pittard, A. J. (1987). Biosynthesis of the aromatic amino acids. In Escherichia coli and Salmonella typhimurium. Cellular and Molecular Biology. Edited by F. C. Neidhart. Washington, DC: American Society for Microbiology.

ROSENBERG, M. \& COURT, D. (1979). Regulatory sequences involved in the promotion and termination of RNA transcription. Annual Review of Genetics 13, 319-353.

SANGer, F., Nicklen, S. \& Coulson, A. R. (1977). DNA sequencing with chain terminating inhibitors. Proceedings of the National Academy of Sciences of the United States of America 71, 5463-5467.

ShINE, J. \& Dalgarno, L. (1974). The $3^{\prime}$ terminal sequence of Escherichia coli 16 S ribosomal RNA: complementarity to nonsense triplets and ribosome binding sites. Proceedings of the National Academy of Sciences of the United States of America 71, 1342-1346.

SOUTHERN, E. (1975). Detection of specific sequences among DNA fragments separated by gel electrophoresis. Journal of Molecular Biology 98, 503-517.

SPROAT, B. S. \& GAIT, M. J. (1985). Chemical synthesis of a gene for Somatomedin C. Nucleic Acids Research 13, 2959-2977.

Strauss, E. C., Kobori, J. A., SiU, G. \& HoOd, L. E. (1986). Specificprimer-directed DNA sequencing. Analytical Biochemistry 154, 353 360.

TABOR, S. \& RICHARDSON, C. C. (1987). DNA sequence analysis with a modified bacteriophage T7 polymerase. Proceedings of the National Academy of Sciences of the United States of America 84, 4767-4771.

TAUTZ, D. \& RENZ, M. (1983). An optimised freeze-squeeze method for the recovery of DNA fragments from agarose gels. Analytical Biochemistry 132, 14-19.

Tinoco, I., Borer, P. N., Dengler, B., Levine, M. D., Uhlenbeck, O. C., Crothers, D. M. \& Gralla, J. (1973). Improved estimation of secondary structure in ribonucleic acids. Nature New Biology $\mathbf{2 4 6}$, $40-41$.

White, J., Millar, G. \& Coggins, J. R. (1988). The overexpression, purification, and complete amino acid sequence of chorismate synthase from Escherichia coli $\mathrm{K} 12$ and its comparison with the enzyme from Neurospora crassa. Biochemical Journal 251, 313-322. 